\title{
Evidence of change in migratory patterns of the ornithofauna in a coastal locality of the Gulf of Mexico during an ENSO event
}

\begin{abstract}
The study of migrations can give us the key for determining changes in avian communities during global events such as El Niño Southern Oscillation (ENSO) phenomenon. For this reason, changes in bird migration patterns were addressed through non-parametric analysis of variance and temporal and beta diversity correlations during an ENSO event at Barra Norte Beach (BN) in Tuxpan, Ver., Mexico. The diversity of birds change from 53 species before the anomalies to 66 during the ENSO event, this gradient of change occurred to the diversity of migratory birds (from 21 to 32 ). These results may be an evidence that the high impact ENSO anomalies can modify bird migration patterns, which is supported by differences in medians richness (especially in migratory birds) as well as by positive and significant values in correlations in beta and alpha diversity. Finally, we conclude that the migratory route of Gulf of Mexico can serve as an alternative for the migration of birds during events such as ENSO phenomenon.
\end{abstract}

Keywords: birds, diversity, migration, ENSO, Mexico
Volume 7 Issue 4 - 2019

\author{
Jimmy Argüelles Jiménez,' Mariana Stephanie \\ Reyes-Reyes, ${ }^{2}$ Juventino Martínez-Cruz, ${ }^{3}$ \\ Indira Valdivia-Torres, ${ }^{3}$ Ana Lilia Gutierréz- \\ Velázquez, ${ }^{2}$ Carlos González-Gándara ${ }^{3}$ \\ 'Instituto de Ciencias Marinas y Pesquerías, Universidad \\ Veracruzana, México \\ ${ }^{2}$ Instituto Tecnológico de Boca del Río, México \\ ${ }^{3}$ Laboratorio de Arrecifes Coralinos, FACBA, Universidad \\ Veracruzana, México
}

Correspondence: Jimmy Argüelles Jiménez, Instituto de Ciencias Marinas y Pesquerías, Universidad Veracruzana, Hidalgo 617, Col. Río Jamapa, C.P. 94290 , Boca del Río,Veracruz, México, Email cayix24@gmail.com

Received: July 10, 2019 | Published: August 30, 2019

\section{Introduction}

On the planet, it is estimated that more than 5,000 species of animals make periodic movements of different magnitudes as part of their daily activities. ${ }^{1}$ Movement from one place to another allows adjustment to changing environmental conditions, and for that reason the daily movements of many animals take place within a single habitat (i.e., local migration). On the other hand, there are periodic movements that allow many species to adjust to the spatial and temporal heterogeneity of the environment, not as an immediate and opportunistic response, but as an adaptive phenomenon, called regional migration, that occur through natural routes where the ideal conditions are present, ${ }^{1,2}$ or failing that, species may change route or as well as their range of distribution, depending on changes in the environment. ${ }^{3}$

In the last two decades, one of the taxonomic groups where the phenomenon of migration has been studied with greater emphasis is that of birds. ${ }^{2,4}$ So far, 340 bird species are recognized in North America that breed north of the Tropic of Cancer and winter south of it. ${ }^{5}$ Four major migratory routes have been identified in America: ${ }^{2}$ 1) that of the Atlantic Ocean (used by few species that fly over the Atlantic from Nova Scotia and eastern Canada to South America), 2) that of the Atlantic coast (used by species that migrate across the Gulf of Mexico from Florida and the southeastern United States to Mexico and the West Indies), 3) that of the Gulf of Mexico (used by species that cross the Gulf of Mexico or its coastal areas, 4) the western or Pacific route (where birds from the western United States and Canada migrate using the Pacific slope coasts as corridors, or, the Western Sierra Madre, Sierra Madre del Sur and the Transmexican
Neovolcanic Axis). ${ }^{2}$ Each of these routes is of vital importance in the migration of birds to their resting and breeding sites; recent studies that address the inventory of avifauna in northern Veracruz where it crosses the migratory route of the Gulf of Mexico, account for it. ${ }^{6,7}$ For example, in the riparian environments of Tuxpan, Veracruz, $56.3 \%$ of avifauna are migratory birds, ${ }^{7}$ while for the neighboring LobosTuxpan Reef System 89\% are migratory birds. ${ }^{6}$ Likewise, 102 new records have been documented for both localities, of which $31 \%$ are migratory birds (winter visitors and passerby). This information is indicative of the great importance of migratory routes, however; the flow of species could be reduced as the population decline of many groups of migratory birds (e.g. chipes, musketeers, hummingbirds) has been documented for various reasons (e.g. habitat loss, pollution). ${ }^{4}$ This situation could be accentuated by extreme cyclical events such as "El Niño-Southern Oscillation" (ENSO). According to Herzog et al., this type of cyclical oscillations can modify or displace the climatic niche of species (i.e., ranges and migration), especially when they are very intense. The aim of this work is to study the effect of one of the most intense ENSOs (period 2015-2016) on the distribution of migratory birds, using alpha and temporal beta diversity. With this study it was expected to find a relationship between the ENSO effect and the temporal beta in a coastal locality of the migratory route of the Gulf of Mexico.

\section{Materials and methods}

The city of Tuxpan, Veracruz, borders to the east with the Gulf of Mexico and is characterized by a strip of coastline divided into two sectors (north and south) as an effect of the mouth of the river Tuxpan. In the northern portion highlights the beach Barra Norte (BN) with an 
extension of $4.86 \mathrm{~km}$ and serves as a gateway for migratory birds to enter the various coastal ecosystems. ${ }^{7}$ The $\mathrm{BN}$ beach is geographically located between the $21^{\circ} 0^{\prime} 42.77^{\prime \prime} \mathrm{N}$ and $97^{\circ} 19^{\prime} 41.74$ ' $\mathrm{W}$ and between $20^{\circ} 58^{\prime} 23.28^{\prime \prime} \mathrm{N}$ and $97^{\circ} 18^{\prime} 17.17^{\prime \prime} \mathrm{W}$.

The ENSO effect 2015-2016 on the distribution of avian fauna was evaluated by means of alpha and temporal beta diversity in two wintering periods: October 2014-May 2015 and October 2015-May 2016. Howell \& $\mathrm{Web}^{9}$ propose that the winter season consists of a period of eight months, which includes the migration that occurs towards the tropics and the tropics towards the temperate environments of North America. During 72 days of sampling, a total of 234 transects and approximately 195 hours of sampling were performed. On each sampled day three systematic linear transects were made along the BN coastline, each transect was $1 \mathrm{~km}$ long and $600 \mathrm{~m}$ wide according to the proposal of Velarde et al.; ${ }^{10}$ the transects were performed walking in the mornings from 07:00 am to 11:00 am.

The observation of bird species was done with the help of binoculars (Vortex). Field guides by Preston, ${ }^{11}$ Howell \& Webb, ${ }^{9}$ Petracci et al., ${ }^{12}$ and Peterson \& Chalif ${ }^{13}$ were used to identify some species. Each recorded species was photographed with various photographic equipment: Nikon Coolpix P100 21x, Nikon D3300 75-300 mm and Nikon Coolpix P900 83x. To establish if the sampling effort was adequate, a species accumulation curve was performed through the Clench model and the Simplex \& Quasi-Newton geometric function; ${ }^{3}$ the evaluation of the model was established through the determination coefficient $\mathrm{r}^{2}$. The matrix of presence and absence of the species was randomized 100 times in EtimateS v 7.5.2 software $^{14}$ and later the observed values were taken to STATISTICA v7 software ${ }^{15}$ where the model was made as described by Jiménez \& Hortal. ${ }^{3}$
The seasonality of registered birds was established according to Howell \& $\mathrm{Webb}^{9}$ criteria: reproductive resident, non-breeding resident, summer residents, winter visitor and passerby; the latter two groups make up the regional migratory birds. The degree of species replacement over time was determined through Moreno \& Halfter ${ }^{16}$ proposal by using the complementarity index $\left(C_{t}\right)$ of Colwell \& Coddington $^{17}$ and a modification of the beta diversity index $(\beta)$ by Whittaker. ${ }^{18}$ The way to measure the degree of differentiation in the composition between species listed, and the percentage of exclusive species in a list was calculated through equation 1 :

$$
C_{t}=\frac{S_{j}+S_{k}-2 V_{j k}}{S_{j}+S_{k}-V_{j k}} \times 100
$$

where $S_{j}$ and $S_{k}$ are the number of species in the list $k$ and $j$ respectively, and $V_{j k}$ is the number of species in common between both lists, in such a way that

$$
C_{t}=\frac{\text { exclusive species from a list }}{\text { combined richness }} \times 100
$$

Whittaker temporal diversity index $\left(\beta_{t W}\right)$ was obtained by dividing the total number of species in a temporary species set ( O $\propto_{t}$ ) by the average diversity $\left(\propto_{t}\right)$ of the list (equation 3 ).

$$
\beta_{t W}=\frac{\text { Ó } \propto_{t}}{\text { average } \propto_{t}}
$$

The index $\beta_{t W}$ was evaluated at two levels (within months and between months), while complementarity was evaluated at a single level (Figure 1).



Figure I (A) Proposal to measure $\beta_{t W}$ diversity within temporal sampling unit, where each $t$ represents a subunit of the temporal sample (e.g. day), and (B) proposed by Moreno \& Halfter (200I) to measure the $\beta_{t W}$ diversity between habitats (here, temporary units). A, alpha diversity; $\mathrm{t}$, subunit of the temporal sample (n); $\beta_{t W}$, temporary beta of a unit of time; $\mathrm{Ct}$, temporal complementarity. 
Finally, to establish whether the diversity $\propto_{t}$, the mean of $\propto_{t}$ (referred here as $\left.\propto_{t p}\right), \beta_{t W}$ and the values of $C_{t}$ are related within and between the two winter seasons, Spearman correlations were carried out, while non-parametric variance analyses were used to detect differences. Both analyses were carried out with InfoStat software. ${ }^{19}$

\section{Results}

74 species of birds were recorded, of which 25 are new records for the northern coastline of Tuxpan, nine for northern Veracruz and three for the coastal plain of the Gulf of Mexico (Eudocimus ruber, Larus glaucocescens y Streptoprocne semicollaris) (Table 1). The Clench model suggests that the expected richness could increase to 81 species, so $91 \%$ of the richness has been recorded (Figure 2).

Table I List of new ornithological records for the coastline Barra Norte of Tuxpan, Veracruz, Mexico

\begin{tabular}{|c|c|c|c|}
\hline Species & $\mathbf{E}$ & Species & $\mathbf{E}$ \\
\hline Order I) Anseriformes & & 13) Numenius americanus Bechstein, $1812 *$ & VI \\
\hline Family I) Anatidae & & 14) Calidris mauri (Cabanis, I857) & VI \\
\hline I) Dendrocygna autumnalis (Linneus I758) & $\mathrm{RR}$ & Family 8) Charadriidae & \\
\hline 2) Oxyura jamaicensis (Gmelin, I789) & $\mathrm{VI}$ & 15) Charadrius nivosus (Cassin, 1858)* & $\mathrm{VI}$ \\
\hline 3) Aythya americana Eyton, 1838 & $\mathrm{VI}$ & 16) Charadrius vociferus Linnaeus, $1758^{*}$ & VI \\
\hline Order 2) Suliformes & & Family 9) Laridae & \\
\hline Family 2) Phalacrocoracidae & & 17) Chlidonias niger (Linnaeus, 1758) & $\operatorname{Tr}$ \\
\hline 4) Phalacrocorax auritus (Lesson, I83I) & $\mathrm{VI}$ & 18) Sterna forsteri Nuttall, $1834 *$ & $\operatorname{Tr}$ \\
\hline Order 3) Pelecaniformes & & 19) Larus glaucescens Naumann, JF, I840** & $\operatorname{Tr}$ \\
\hline Family 3) Ardeidae & & Order 7) Columbiformes & \\
\hline 5) Ardea herodias Linnaeus, 1758 & $\operatorname{Tr}$ & Family (0) Columbidae & \\
\hline 6) Egretta caerulea (Linnaeus, I758) & $\mathrm{RR}$ & 20) Zenaida macroura (Linnaeus, 1758) * & $\operatorname{Tr}$ \\
\hline 7) Egretta rufescens (Gmelin, JF, I789)* & $\operatorname{Tr}$ & Order 8) Apodiformes & \\
\hline 8) Bubulcus ibis (Linnaeus, 1758) & $\mathrm{RR}$ & Family Apodidae & \\
\hline 9) Butorides virescens (Linnaeus, 1758) & $\mathrm{RR}$ & 21) Streptoprocne semicollaris (DeSaussure, 1859) ** & $\operatorname{Tr}$ \\
\hline Familia 4) Threskiornithidae & & Order 9) Coraciiformes & \\
\hline 10) Eudocimus ruber (Linnaeus, 1758)** & $\operatorname{Tr}$ & Family II) Alcedinidae & \\
\hline Order 4) Accipitriformes & & 22) Megaceryle torquata & $\mathrm{RR}$ \\
\hline Family 5) Accipitridae & & 23) Megaceryle alcyon (Linnaeus, I758) & $\operatorname{Tr}$ \\
\hline II) Rupornis magnirostris (Gmelin, JF, I 788) & $\mathrm{RR}$ & Order 10) Falconiformes & \\
\hline Order 5) Gruiformes & & Family 12) Falconidae & \\
\hline Family 6) Rallidae & & 24) Falco femoralis Temminck, 1822 & VI \\
\hline I2) Fulica americana Gmelin, JF, I789 & $\mathrm{VI}$ & Order II) Passeriformes & \\
\hline Order 6) Charadriiformes & & Family 13) Icteridae & \\
\hline Family 7) Scolopacidae & & 25) Psarocolius montezuma (Lesson, I830) & RR \\
\hline
\end{tabular}

* New record for northern Veracruz, ** New record for the Gulf of Mexico Plain, E, seasonality; RR, reproductive resident; $\mathrm{VI}$, winter visitor; Tr, passerby. 


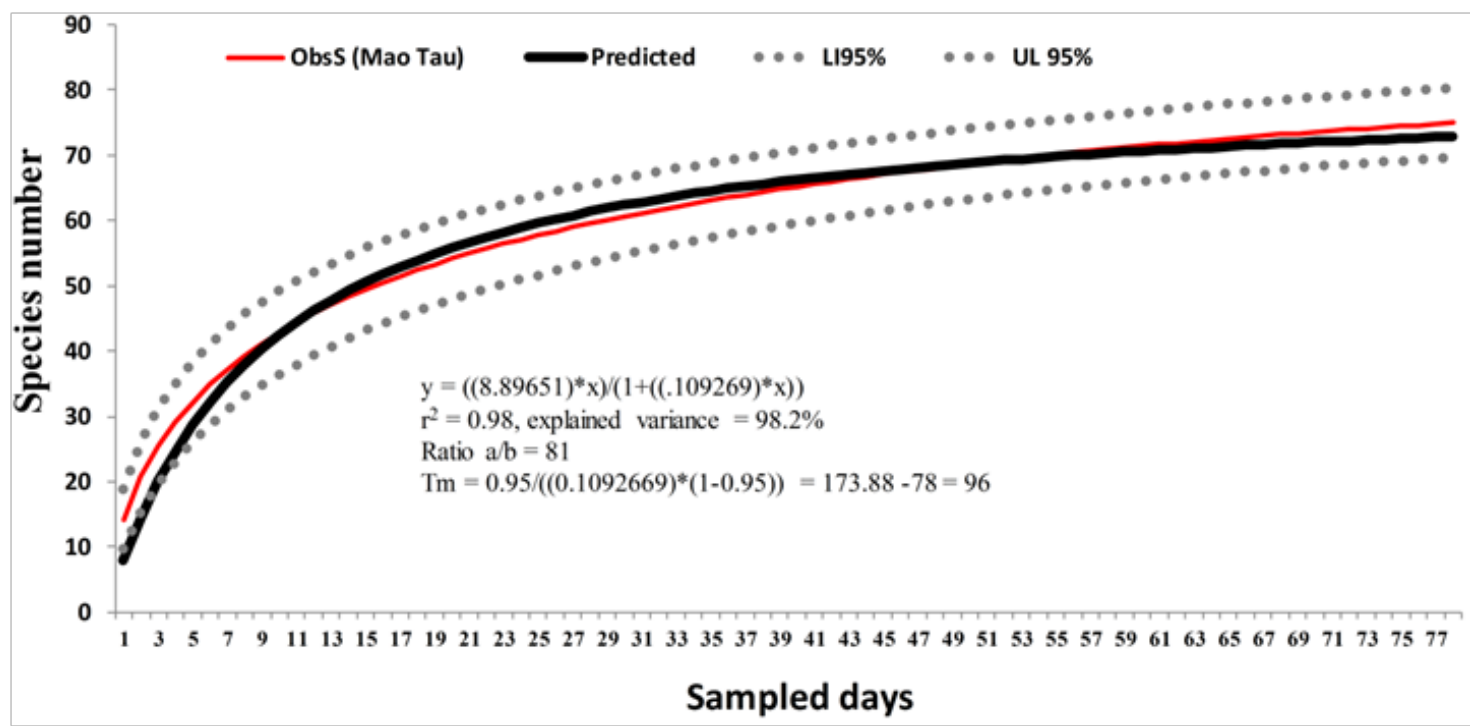

Figure 2 Cumulative curve of species observed and expected for the Barra Norte of Tuxpan, Veracruz.ObsS, observed species; LI, lower limit; UP, upper limit

Of the registered birds, $47.3 \%$ are considered resident (32 spp. are reproductive, two non-breeding and one is summer resident), while $52.7 \%$ are migratory (22 spp. are winter visitors and 17 passersby). The importance of the seasonality of these groups increased during ENSO year, where the number of passersby species increased from 9 to 14 species (Riparia riparia, Hirundo rustica, Egretta rufescens, Eudocimus ruber, Megaceryle alcyon, Streptoprocne semicollaris, Zenaida macroura, Pluvialis dominica, Larus delawarensis, L. glaucescens Leucophaeus pipixcan, Sterna hirundo, S. forsteri, Chlidonias niger), while the number of winter visitors increased from 12 to 17 species (Oxyura jamaicensis, Athya americana, Falco peregrinus, F. femoralis, Plegadis chihi, Phalacrocorax auritus, Calidris minutilla, C. alba, C. mauri, Charadrius semipalmatus, $C$. alexandrinus, $C$. vociferus, $P$. squatarola, Fulica americana, $L$. californicus, L. argentatus, Hydroprogne caspia).

Regarding the values of $\propto_{t}, \propto_{t p}$ and $\beta_{t W}$, increases were observed as ENSO progressed and developed (Figure 3), reflected in the specific richness with an increase from 53 to 66 species. Nine species did not occur during ENSO (Tyrannus forficatus, Pelecanus erythrorhynchos, Dendrocygna autumnalis, Platalea ajaja, Numenius americanus, $C$. fuscicollis, C. wilsonia, Rissa tridactyla, Vireo philadelphicus,), while 22 were exclusive to the ENSO event (O. jamaicensis, A. americana, Bubulcus ibis, E. ruber, M. alcyon, F. femoralis, P. auritus, Columbina inca, C. alba, C. mauri, C. semipalmatus, C. alexandrinus, C. vociferus, $P$. squatarola, $P$. dominica, $F$. americana, Ruporornis magnirostris, S. semicollaris, Z. macroura, L. glaucescens, S. forsteri, C. niger).

The increase in diversity changes is corroborated by the analysis of non-parametric variance. On the scale within months the values of $\propto_{t}, \propto_{t p}$ and $\beta_{t W}$ are different before and during ENSO, while the scale between months only detects differences in the values of $\propto_{t}$ and $\propto_{\text {tp }}$ (Table 2)

Table 2 Analysis of non-parametric variance between the variables of interest

\begin{tabular}{|c|c|c|c|c|c|c|c|}
\hline \multirow{2}{*}{ Variables } & \multirow{2}{*}{$\mathbf{n}$} & \multicolumn{2}{|c|}{ Median } & \multirow{2}{*}{ gl } & \multirow{2}{*}{ C } & \multirow{2}{*}{$\mathbf{H}$} & \multirow{2}{*}{$\mathbf{p}$} \\
\hline & & BE & D & & & & \\
\hline$\propto_{t}$ & 8 & 31.5 & 20 & I & I & 7.75 & 0.0031 \\
\hline$\propto_{t p}$ & 8 & 15.13 & 12.63 & 1 & I & 7.46 & 0.0042 \\
\hline$\beta_{t W}$ & 8 & 2.13 & 1.73 & $\mathrm{I}$ & I & 3.98 & 0.0462 \\
\hline$\propto_{t}$ & 7 & 33 & 19 & I & I & 9.8 & 0.0006 \\
\hline$\propto_{t p}$ & 7 & 24.5 & 14 & 1 & 0.99 & 9.8 & 0.0006 \\
\hline
\end{tabular}

BE, before ENSO; D, during ENSO;Wi, within months; Bet, between months 
In general, $\beta_{t W}$ positively and significantly correlates with $\propto_{t}$ and $C_{t}$ within and between months (Table 3); which indicates that as the effect of the ENSO increases, so does the number of species, as well as the degree of species replacement.

Table 3 Positive and significant correlations between the variables of interest before and during ENSO at two scales: within months (Wi) and between months (Bet).

\begin{tabular}{lllll}
\hline Correlations & $\mathbf{n}$ & Sperman & $\mathbf{p}$ \\
Wi & $\propto_{t}$ vs $\propto_{t p}$ & 16 & 0.89 & $<0.000 \mathrm{I}$ \\
& $\propto_{t}$ vs $\beta_{t W}$ & 16 & 0.71 & 0.0022 \\
Bet & $\propto_{t}$ vs $\propto_{t p}$ & 14 & 0.92 & $<0.000 \mathrm{I}$ \\
& $\beta_{t W}$ vs $C_{t}$ & 14 & 0.85 & $0.000 \mathrm{I}$
\end{tabular}

Finally, the correlation analysis shows that $\beta_{t W}$ is a dependent scale, so the correlative results vary when analyzed within and between units of time. $\beta_{t W}$ correlates positively and significantly with the alpha diversity before ENSO year, while during the ENSO it correlates with the $C_{t}$ in the analysis within months (Table 4).

Table 4 Positive and significant correlations between the variables of interest before and during ENSO at two scales: (a) within months and (b) between months.

\begin{tabular}{lccll}
\hline (a) Correlations-Wi & $\mathbf{n}$ & Sperman & $\mathbf{p}$ \\
\hline & $\propto_{t}$ vs $\propto_{t p}$ & 8 & 0.69 & 0.0578 \\
BE & $\propto_{t}$ vs $\beta_{t W}$ & 8 & 0.79 & 0.0202 \\
& & & & \\
D & $\propto_{t}$ vs $\propto_{t p}$ & 8 & 0.89 & 0.0034 \\
\hline & & & & \\
(b) Correlations-Bet & $\mathbf{n}$ & Sperman & $\mathbf{p}$ \\
& & & & \\
BE & ${ }_{t}$ vs $\propto_{t p}$ & 7 & 0.88 & 0.009 \\
& $\beta_{t W}$ vs $C_{t}$ & 7 & 0.84 & 0.019 \\
D & $\beta_{t W}{ }_{\text {vs }} C_{t}$ & 7 & 0.99 & $<0.0001$ \\
\hline
\end{tabular}

$\mathrm{BE}$, before ENSO; D, during ENSO;Wi, within months; Bet, between months

\section{Discussion}

The position of Mexico between two biogeographic regions (Neartic and Neotropical), and the complex orography have enabled the existence of a large number of environments, where forests such as the high perennifolia and the low deciduous concentrate the highest percentage values of the avian diversity of Mexico (29 and 24\% respectively). In contrast, freshwater lakes (6.7\%), coastal waters $(5.4 \%)$ and pelagic waters $(3.3 \%)$ have low richness values. ${ }^{20}$ This pattern explains that the registered diversity only represents $10.3 \%$ of the 717 registered species for the state of Veracruz. ${ }^{21}$ Despite this, the 74 species surveyed exceed the average values reported by NavarroSinguenza et al., ${ }^{20}$ for several sandy (45 spp.) and rocky (14 spp.) beaches, as well as for brackish marshes (45 spp.), coastal waters (57 spp.) and pelagic waters ( $35 \mathrm{spp}$.) in Mexico. This high ("anomalous") diversity may be the result of natural fluctuations in local and regional bird migration patterns, or it may indicate a maladjustment caused by the ENSO effect studied.

When comparing the richness recorded with that reported for the northern coastline of Tuxpan 725 new records are added, so that the listing of this environment increases to 81 species. On the other hand, and through the review of existing literature ${ }^{6,7,10,22}$ and specialized websites ${ }^{23-25}$ nine records are provided for the northern region of Veracruz, of which Eudocimus ruber, Larus glaucocescens and Streptoprocne semicollaris had not been recorded until now for the biogeographic province of the Gulf of Mexico. ${ }^{26}$ Registration of these species may be considered rare for the region, e.g. E. ruber is commonly distributed in northern South America, however, sightings have been reported in Guatemala as well as in southern Florida. ${ }^{25}$ It is therefore likely that the sightings of these organisms are errant movements or, failing that, extensions of their ecological niche as a result of climate change. $8,27,28$

Of the registered birds, $47.3 \%$ are considered resident (32 spp. are reproductive, two non-breeding and one summer resident), while migratory birds make up 52.7\% (22 spp. winter visitors and 17 passerby). The largest migratory component recorded in this study was similar to that reported by Argüelles et al., ${ }^{6,7}$ for the coastal environments of Tuxpan (e.g. reefs, river, lagoon, estuaries), which allows us to assume that the region fulfills its function as part of the migration route of the Gulf of Mexico. However, the previous record of avifauna for the northern coastline of Tuxpan mentioned by Argüelles et al. ${ }^{7}$ shows that the proportion of resident birds is higher $(55.4 \%)$ than that of migratory birds (44.6\%), which could be indicative of an increase in the migration process during the study period.

In relation to the values of $\propto_{t}, \propto_{t p}$ and $\beta_{t W}$, Figure 3 denotes the increase of these values as the ENSO phenomenon advances in the scale within months, while in the second temporal scale this is not observed in the values of $\beta_{t W}$. The analysis of variance confirms that the median values of $\propto_{t}, \propto_{t p}$ and $\beta_{t W}$ are higher after the ENSO event on both scales, with the exception of the $\beta_{t W}$ on the scale between months. The correlation analysis shows $\beta_{t W}$ correlates positively and significantly with the alpha before ENSO event, while during ENSO within months correlates with $C_{t}$, indicating that as the effect of ENSO increases so does the number of species, as well as the degree of species replacement increases. Also, these results indicate that the $\beta_{t W}$ is a dependent scale, so the correlative results vary when analyzed within and between time units. Studies carried out at the spatial scale level suggest that $\beta$ diversity is a dependent scale, and that it increases at finer scales, ${ }^{29-31}$ as in the present study where the increase is observed on the scale within months.

Studies such as Pearson \& Dawson, ${ }^{27}$ which analyzes existing information on the impacts of climate change on species distribution, show that these changes have a profound influence on the range of 
expansion and contraction of their distribution. Research carried out in the Mexican Pacific determines that the population density of seagulls, their reproductive success and the number of chicks are affected during ENSO events. ${ }^{32,33}$ When the ENSO event is of low magnitude, breeding seabirds tend to increase the number of chicks as a survival strategy, whereas when those events are very strong, reproductive and breeding success decrease, ${ }^{32}$ as a result, some species such as Thalasseus elegans have chosen to expand their range of distribution to areas where they can potentially reproduce. ${ }^{34}$ Thus, the modification of the climatic niche of species, ${ }^{8}$ as well as the lack of food provision ${ }^{32,33}$ during a high impact ENSO could contribute to migratory species tending to change routes towards those with greater affinity, which could be happening in the Gulf of Mexico. The latter is supported by the differences in medians and the significant correlations detected in this study.

Finally, on the Gulf of Mexico side there are large information gaps in avian fauna (e.g. population ecology, reproductive strategies, food), especially when addressing the effect of an ENSO event, despite this the present document lays the groundwork that strong ENSO phenomena could modify the migratory strategies of birds by changing the migratory route

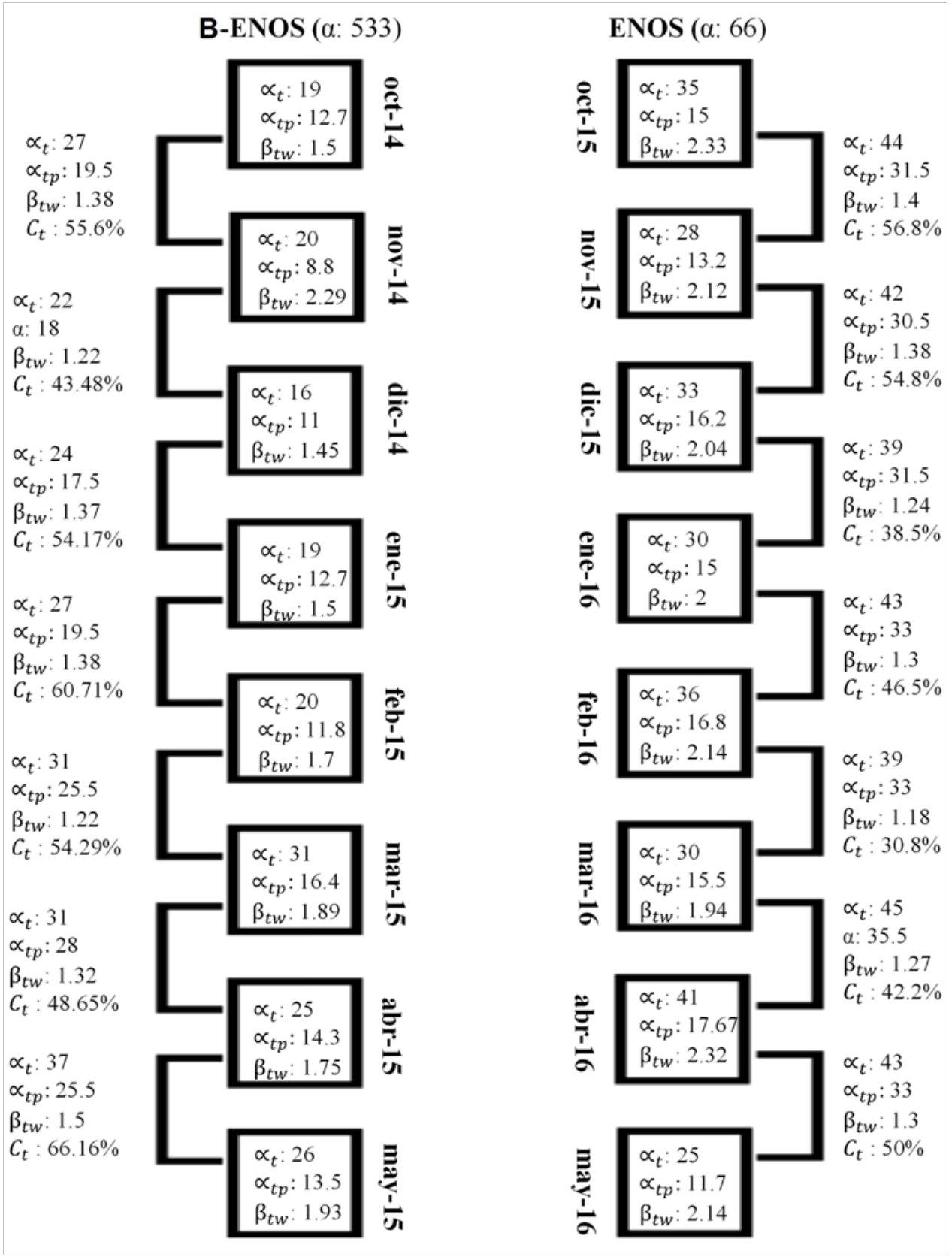

Figure 3 Values of $\propto_{t}, \propto_{t p}, \beta_{t W}$ and $C_{t}$ within and between the months that compose the winner season before and during the ENSO. B-ENOS: before el niño oscillation south and ENOS: el niño oscillation south. 


\section{Conclusions}

The 74 bird species recorded represent $10.3 \%$ of the 717 species recorded for the state of Veracruz. The richness specifies increase as the ENSO developed, especially in migratory birds (from 21 to 32 species). At the beginning of this document, it was suggested that through the analysis of alpha and temporary beta diversity, patterns of change in migratory routes could be evidenced; without discarding patterns of natural fluctuations of the birds, the differences detected by the analysis of variance and the positive and significant correlations suggest an increase in bird richness as the ENSO event develops. In this way, the migratory route of the Gulf of Mexico would tend to be optimal as a migratory corridor when the climate of other migratory routes is modified.

\section{Acknowledgments}

To the financing granted through the project "Bases para el Análisis y Síntesis de los Sistemas Costeros Veracruzanos", by the Red para el Análisis y Síntesis de la Zona Costera Veracruzana del Golfo de México (RASZCOV).

\section{Conflicts of interest}

Authors declare that there is no conflict of interest.

\section{References}

1. Naranjo LG, Amaya JD, Eusse-González D, et al. Guía de las especies migratorias y de la biodiversidad en Colombia, volumen 1. Bogotá, Colombia: Ministerio de Ambiente y Desarrollo Sostenible \& WWF Colombia; 2012. 710 p.

2. Lincoln FC, Peterson SR, Zimmerman JL. Migration of birds. U.S. Washington, D.C.: Department of the Interior, U.S. Fish and Wildlife Service, Circular 16; 1998.

3. Jiménez-Valverde A, Hortal J. Las curvas de acumulación de especies y la necesidad de evaluar la calidad de los inventarios biológicos. Revista Ibérica de Aracnología. 2003;8:151-161.

4. Medellin RA, Abreu-Grobois A, Arizmendi MC, et al. Conservación de especies migratorias y poblaciones fronterizas. En CONABIO. Capital natural de México, vol. II: Estado de conservación y tendencias de cambio. México: Comisión Nacional para el Conocimiento y Uso de la Biodiversidad; 2009. 459-515 p.

5. Rappole JH. The ecology of migrant birds: A neotropical perspective. Washington, D.C.: Smithsonian Institution Press; 1995.

6. Argüelles-Jiménez J, Macías-Hernández S, González-Gándara C, et al. Ornitofauna de los arrecifes coralinos del norte de Veracruz, México. En A Granados-Barba, Ortiz-Lozano L, Salas-Monreal D, et al. (Eds.). Aportes al conocimiento del Sistema Arrecifal Veracruzano: hacia el Corredor Arrecifal del Suroeste del Golfo de México. Campeche, México: Universidad Autónoma de Campeche; 2015. 351-366 p.

7. Argüelles-Jiménez J, Macías-Hernández S, Rojas-Terán MA, et al. Aves ribereñas de los ecosistemas costeros de Tuxpan, Veracruz, México. Ecosistemas y Recursos Agropecuarios. 2017;4(10):147-159.

8. Herzog KS, Jørgensen PM, Martínez RG, et al. Efectos del cambio climático en la biodiversidad de los Andes tropicales: el estado del conocimiento científico. São José dos Campos, Brasil: Instituto Interamericano para la Investigación del Cambio Global; 2010.

9. Howell SNG, Webb S. A guide to the birds of Mexico and Northern Central. USA: Oxford University Press; 2004
10. Velarde-González ME, Martínez-Villasis A, Gallardo del Ángel JC. Las aves del sistema arrecifal veracruzano. En BA Granados, Abarca ALG, Vargas HJM. (Eds.) Investigaciones Cientificas en el Sistema Arrecifal Veracruzano. Campeche, México: Universidad Autónoma de Campeche; 2007. 27-50 p.

11. Preston EE. A field guide of the birds of Mexico and adjacent areas Belize, Guatemala, and El Salvador. USA: University of Texas Press; 1998.

12. Preston EE. A field guide of the birds of Mexico and adjacent areas Belize, Guatemala, and El Salvador. USA: University of Texas Press; 1998.

13. Peterson RT, Chalif EL. Aves de México: Guía de campo identificación de todas las especies encontradas en México, Guatemala, Belice y el Salvador. México: Editorial Diana; 2008.

14. Colwell RK. EstimateS statistical estimation of species richness and shared species from samples, version 7.5. USA: Uniersity of Connecticut; 2006.

15. STATISTICA (data analysis software system), versión 7. USA: StatSoft; 2004.

16. Moreno CE, Halffter G. Spatial and temporal analysis of $\alpha, \beta$ and $\gamma$ diversities of bats in a fragmented landscape. Biodiversity \& Conservation. 2001;10(3):367-382.

17. Collwell RK, Coddington JA. Estimating terrestrial biodiversity through extrapolation. Philospphical Transactions of the Royal Society of London, 1994;345(1311):101-118.

18. Whittaker RH. Evolution and measurement of species diversity. Taxon. $1972 ; 21(2-3): 213-251$.

19. Di Rienzo JA, Casanoves F, Balzarini MG, et al. InfoStat, versión 2008. Argentina: Universidad Nacional de Córdoba, Grupo InfoStat, FCA; 2008.

20. Navarro-Singuenza AG, Rebón-Gallardo MF, Gordillo-Martínez A, et al. Biodiversidad de aves en México. Revista Mexicana de Biodiversidad. 2014;85(Suppl 1):476-495.

21. Gallardo-del Ángel JC, Aguilar RSH. Aves: diversidad distribución y conservación. En AA Cruz (Ed). La biodiversidad en Veracruz: estudio de Estado: Contexto actual del estado y perspectivas de conservación de su biodiversidad. Vo. II. Ciudad de México: Comisión Nacional para el Conocimiento y Uso de la Biodiversidad, Gobierno del Estado de Veracruz, Universidad Veracruzana, Instituto de Ecología Asociación Civil; 2011. 559-578 p.

22. Serrano A, Vázquez-Castán L, Ramos-Ramos M, et al. Diversidad y abundancia de aves en un humedal del norte de Veracruz, México. Acta Zoológica Mexicana. 2013;29(3):473-485.

23. Berlanga H, Rodríguez-Contreras V, Oliveras de IA, et al. Red de conocimientos sobre las aves de México (AVESMX). Comisión Nacional para el Uso y Conocimiento de la Biodiversidad; 2008.

24. Partnership for nature and people. BirdLife; 2017.

25. Cornell-The birds of North America. Species. Birds of North America Online; 2017.

26. Provincias biogeográficas de México. Comisión Nacional para el Uso y Conocimiento de la Biodiversidad (CONABIO); 1997.

27. Pearson RG, Dawson TP. Predicting the impacts of climate change on the distribution of species: are bioclimate envelope models useful? Global Ecology \& Biogeography. 2003;12(5):361-371.

28. Peterson TA, Martínez-Meyer E, González-Salazar C, et al. Modeled climate change effects on distribution of Canadian butterfly species. Canadian Journal Zoology. 2004;82(6):851-858. 
29. Lennon JJ, Koleff P, Greenwood JJ, et al. The geographical structure of British bird distributions: diversity, spatial turnover and scale. Journal of Animal Ecology. 2001;70(6):966-979.

30. Ochoa-Ochoa LM, Munguía M, Lira-Noriega A, et al. Spatial scale and $\beta$-diversity of terrestrial vertebrates in Mexico. Revista Mexicana de Biodiversidad. 2007;85(3):918-930.

31. Zhang Y, Ma K, Anand M, et al. Scale dependence of beta diversity-scale relationship. Community Ecology. 2015;16(1):39-47.
32. Velarde E. Breeding biology of Heermann's Gulls on Isla Rasa, Gulf of California, Mexico. Auk. 1999;116(2):513-519.

33. Velarde E, Ezcurra E, Cisneros-Mata MA, et al. Seabird ecology, el Niño anomalies, and prediction of sardine fisheries in the Gulf of California. Ecological Applications. 2004;14(2):607-615.

34. Velarde E, Ezcurra E, Horn MH, et al. Warm oceanographic anomalies and fishing pressure drive seabird nesting north. Ecology. 2015;1(5):1-7. 